\title{
Scanning Electron Microscopy of Reproductive Epithelia in the Female Musk Shrew, Suncus murinus
}

\author{
Eric D. WIKRAMANAYAKE \& Gilbert L. DRYDEN
}

Wikramanayake E. D. \& Dryden G. L., 1986: Scanning electron miscroscopy of reproductive epithelia in the female musk shrew, Suncus murinus. Acta theriol., 31, 10: 129-136 [With Plates I-V]

Surface cells of adult musk shrew ovaries are wrinkled or rounded, presenting a cobblestone-like appearance. Those of estrogen-treated and untreated shrews are often collapsed but those of the HCG-treated shrews are rounded. Epithelial cells of the fungiform corpora lutea are rounded, polyhedral, or attenuated. They are larger than the germinal epithelial cells and persist $70 \mathrm{hr}$ after ovulation. Fimbrial epithelia consist of both ciliated and non-ciliated cells, those of treated and young, untreated shrews being most ciliated. Oviducal epithelia are heavily folded and extensively ciliated. Ciliation extends caudally over $60-70 \%$ of the oviducal length after which it occurs only in sparse, isolated patches. Ciliation is absent near the utero-tubal junction, the epithelium consisting of shallow, longitudinal folds bearing abundant microvilli. The uterotubal junction projects into the uterine lumen, with abundant microvilli on its rounded surface cells. Uterine epithelia are moderately folded with numerous microvilli on the apices of rounded cells. Endometrial microvilli of treated shrews are elongated in some areas and associate with secretory blebs. Cervical epithelia consist of flat, microvillous cells surrounding shallow depressions, possibly gland openings. Fornical epithelia are flat and keratinized. Vaginal epithelia of both treated and untreated shrews are deeply plicated longitudinally but this plication is obscured caudally by exfol:ation of rounded squamous epithelium. Vaginal surface cells are covered with dense, stubby microvilli causing them to appear fuzzy. The untreated shrew vaginal epithelium is characterized by elaborate microridge arrangements.

[Department of Wildlife and Fisheries Biology, University of California, Davis, CA 95616 and Biology Department, Slippery Rock University, Slippery Rock, PA 16057, U.S.A.]

\section{INTRODUCTION}

The ultrastructure of the female reproductive tract has been studied extensively and described for many mammalian groups (e.g., Ferenczy et al., 1972; Johannisson \& Nilsson, 1972; Kanagawa et al., 1972; Verhage et al., 1973a; Hayashi \& Matsukawa, 1979; Takahashi et al., 1980) but similar investigations are lacking in Insectivora even though these animals represent a diverse and ancient eutherian order. Although some studies of reproductive epithelia are descriptive (Nalbandov, 1969; Ferenczy et al., 1972; Hafez, 1972), others treat morphological changes 9 - Acta Theriologica [129] 
that occur during the reproductive cycle (Verhage et al., 1973a; Parakkal, 1974; Rumery et al., 1978) and after exogenous hormonal treatment (Brenner, 1967; Odor et al., 1981, 1983). These changes include ciliogenesis, secretory processes, and changes in cell shape and composition.

Information on the reproductive physiology of the female Asian musk shrew, Suncus murinus, is accumulating (Dryden, 1969, 1985; Dryden \& Pucek, 1976; Dryden \& Anderson, 1977; Hasler \& Nalbandov, 1978, 1980; Keefer \& Dryden, 1982). Only light microscopic descriptions of its reproductive tract exist (Deshpande, 1958; Dryden, 1969; Naik \& Dominic, 1970; Sabnis, 1973), however, and these afford limited insight into structural changes associated with different phases of tract differentiation and function. This paper documents the surface fine structure of the S. murinus female reproductive tract, including the effects of estrogen treatment on its lưminal epithelia.

\section{MATERIAL AND METHODS}

The shrews were taken from a previously described laboratory colony (Dryden, 1968, 1975). Fifteen adult females were killed with ether, their tracts removed and immediately placed in chilled $0.2 \mathrm{M}$ sodium phosphate buffer $(\mathrm{pH} 7.2$ ). Oviducts were carefully straightened, pinned to a dental wax base and fixed in $3 \%$ gluteraldehyde for $2 \mathrm{hrs}$. Ovaries were removed and the tract divided into sections. Oviducts (except fimbriae) and uteri were dorsoventrally split and vaginae were divided into dorsal and ventral halves. Tissues were then washed in phosphate buffer, $16 \%$ glycerol sodium-phosphate buffer $(24 \mathrm{hrs})$, post fixed in $2 \%$ osmium tetraoxide $(1 \mathrm{hr})$, dehydrated in an ethanol series, critical point dried (Sorval system), mounted and sputter coated with $200 \AA$ of gold palladium. Observations were with a Coates and Welter (Cwikscan 106A) field emission SEM.

Tracts of 4 untreated shrews were examined. Four shrews were treated with $0.25 \mathrm{~g}$ of estradiol injected subcutaneously daily for 8 days and dissected on day 9. Ovaries of 7 other shrews were examined at intervals after treatment with 50 IU of HCG injected subcutaneously to induce ovulation (Dryden \& Pucek, 1976) in this non-cyclic form (Dryden, 1969). Estradiol treatment was to determine its effects on tract epithelium development. Induced ovulation provided corpora lutea for surface examination.

\section{RESULTS}

\section{Ovary and Corpus Luteum}

Most epithelial cells of untreated and estradiol-treated ovaries appeared collapsed, the free surface being wrinkled (Fig. 1). While this may be artefactual, patches of uncollapsed, domed cells presented a cobblestone-like arrangement in other places (Fig. 2). Both cell types bore microvilli (Fig. 3). Germinal epithelial cells of post-ovulated ovaries were rounded 
or slightly polyhedral. The relatively large, fungiform corpora lutea (Fig. 4), were paved with polyhedral, rounded or attenuated cells (Fig. 5) invariably larger than the adjacent ovarian epithelial cells (Fig. 6, Plate I).

\subsection{Oviduct}

The fimbrial surface was extensively folded, its epithelial surface comprised of a mixed population of nonciliated and ciliated cells with microvilli on the former (Fig. 7). Although most nonciliated cells were dome shaped, some polyhedral and exfoliating (also polyhedral) cells were also present (Fig. 8, Plate II).

No differences in oviducal epithelia were evident between treated and untreated shrews. Epithelia in the ampullary region were heavily plicated and extensively ciliated (Fig. 9). A few nonciliated cells were present (Fig. 10) but not as many as in the fimbriae. This extensive persisted throughout approximately $60-70 \%$ of the oviducal length but decreased dramatically towards the cornual end where cilia occurred only in scattered patches (Fig. 11). Nonciliated cells in this region bore abundant microvilli on their luminal surfaces. Epithelial folding was also reduced. Cilia were completely absent above the utero-tubal junction; the epithelium consisting of microvillous cells only. Topography was reduced to shallow longitudinal folds (Fig. 12, Plate III). Some surface secretions were present, especially in the distal oviduct. The utero-tubal junction projected into the uterus as a tri-lobed, patent nipple bearing dome-shaped cells with dense aggregations of short, stubby microvilli (Fig. 13).

\subsection{Endometrium}

Uterine epithelia were moderately folded, but these folds were not consistently oriented as near the utero-tubal junction. However, projecting endometrial cells apices presented a rather uniform topology covered with numerous microvilli (Fig. 14). In treated shrews some epithelial cells were characterized by prominent, elongated apical microvilli (Fig. 15). These were rarely seen in untreated shrews. Secretory blebs (Fig. 16) were present in all uteri but were more numerous in treated shrews. Blebs were found only on certain areas of the uterine epithelia; elongated endometrial microvilli of treated shrews were also inconsistently distributed. Cervical epithelia were flat with numerous stubby microvilli, somewhat resembling the uterine epithelium but otherwise unremarkable (Fig. 17). Shallow depressions were present among them. 


\subsection{Vagina}

Fornical epithelia were flat and keratinized with neither cilia nor microvilli (Fig. 18, Plate IV). The more distal vaginal squamous epithelium was characterized by numerous longitudinal folds bearing attenuated cells. Individual cells were most discernible towards the cranial end of the vagina in both untreated (Fig. 19) and treated shrews (Fig. 20). A prominent feature of the vaginal epithelium in untreated shrews was the presence of an elaborate system of microridges (Figs. 20, 21). Although some vaginal microridges were present in treated shrews they were neither as elaborate nor as common as in the untreated animals. Vaginal plication extended caudally towards the urogenital sinus but fold outlines were partially obliterated by extensive exfoliation of rounded cells. In both treated and untreated shrews the cells were covered with dense aggregations of short microvilli, creating a fuzzy appearance (Fig. 22, Plate V).

\section{DISCUSSION}

Transmission electron microscopy of the hamster ovary revealed detaching germinal epithelial cells and cytoplasmic fragments (Weakley, 1969) while cell exfoliation was seen in the human tract (Ludwig \& Metzger, 1976). Thus the wrinkled, collapsed nature of the S. murinus ovarian epithelium may be due to degeneration preceding exfoliation. Similarly, the uncollapsed cells of the recently ovulated ovary may be attributed to increased surface mitoses associated with reconstitution of the ovarian epithelium over the extruded, fungiform, corpus luteum (Dryden, 1969). Although complete envelopment of the $37-54 \mathrm{hr}$ postovulatory corpus luteum by the germinal epithelium is reported (Dryden, 1969), the $70 \mathrm{hr}$ post-ovulatory luteal surface cells observed in the present study were similar to the $39 \mathrm{hr}$ cells. Further work involving correlative TEM is required to clarify corpus luteum surface cifferentiation and variability in this species.

Three animals were 6-10 months older than the others; two were subjected to estrogen treatment whereas one was not treated. The fimbriae of the former were extensively ciliated but those of the untreated shrew were paved with almost equal numbers of ciliated and nonciliated cells. All other animals had extensively ciliated fimbriae irrespective of treatment. Oviducal ciliary condition was similar in all animals. Thus, estrogen treatment may have resulted in reciliation of fimbrial epithelium in older animals. This is consistent with other mammalian groups were oviducal and/or fimbrial ciliation was induced by exogenous estrogen therapy (Brenner, 1969; Verhage et al., 1973b; 
Verhage and Brenner, 1975; Odor et al., 1983). Further, fimbrial ciliation of primates is apparently more sensitive to plasma estrogen-progesterone levels than in other oviducal regions (Rumery et al., 1978; Brenner, 1969). Since Suncus is a reflex ovulator, oviducal ciliation might be extensive even without estrogen treatment. This would agree with Brower and Anderson's (1969) failure to detect a cyclicity of ciliogenesis in the rabbit, another reflex ovulator. External boundaries between ampulla-isthmus and isthmus-junctura have not been established for $S$. murinus oviducts. Specific designation of where ciliation decreases and stops in relation to the oviducal subdivisions is therefore difficult to fix, even though the transition is relatively abrupt. Interestingly, differentiated epithelial crypts peculiar to the isthmus of this species may confer acrosomal stability on ejaculated sperm (Bedford et al., 1984).

Elongated microvilli present on some endometrial cell apices of treated shrews (Fig. 15) appear similar to the "sea-anemone like" structures on progesterone-treated endometria of rats described by Psychoyos \& Mandon (1971). Extrusion of secretory blebs was observed at these points in S. murinus. Both blebs and elongated microvilli were confined to certain areas of the epithelium, possibly in association with the antimesometrially and laterally localized endometrial glands described by Dryden (1966). Selagen et al. (1982) reported similar secretory structures and elongated endometrial microvilli in rabbits. No uterine or cervical cilia were present, contrasting with the situation in some other mammalian groups investigated (Hafez, 1972; Hayashi \& Matsukawa, 1979).

The elaborate arrangements of microridges present in the untreated vaginal epithelium (Figs. 20,21) have been interpreted as possible coital aids in mice (Lamb et al., 1978) since they may retain and spread mucus (Sperry \& Wasserburg, 1976). However, Ludwig \& Metzger (1976) suggest that they may serve to interlock and bind adjacent cell layers. Similar "microfolds" on the apical surfaces of possum epididymides phagocytize sperm cytoplasmic droplets (Temple-Smith, 1984). Perhaps microridges of the shrew vagina remove luminal detritus. Estradiol treatment of shrews resulted in disappearance of the microridges, or in some instances, reduction in the complexity.

Although Dryden \& Anderson (1977) found that the female reproductive trace of $S$. murinus did not exhibit significant gross morphological or histological responses to ovariectomy and exogenous estradiol treatment, thus indicating an apparent insensitivity to it, there are "normal" populations of estradiol receptors in the uterine and vaginal epithelia (Keefer \& Dryden, 1982). The results of this study show that ultrastructural changes occur in the uterine epithelia when subjected 
to estradiol treatment even though these changes are not discernible with light microscopy. The results also suggest that oviducal and vaginal epithelia may be even more sensitive to estrogen but, this must be quantified.

Acknowledgements: We thank Mark Chase for technical assistance and Claudia Errera for typing the manuscript.

\section{REFERENCES}

1. Bedford J. M., Rodger J. C. \& Breed W. G., 1984: Why so many mammalian spermatozoa - a clue from marsupials. Proc. R. Soc. Lond., B221: 221-233.

2. Brenner R. M., 1967: Electron microscopy of estrogen effects on ciliogenesis and secretory cell growth in rhesus monkey oviduct. Anat. Rec., 157: 218-219.

3. Brenner R. M., 1969: The biology of oviducal cilia [In: "The Mammalian Oviduct", Eds. E. S. E. Hafez \& R. J. Blandau]. The Univ. Chicago Press: 203-229. Chicago.

4. Brower L. K. \& Anderson E., 1969: Cytological events associated with the secretory process in the rabbit oviduct. Biol. Reprod., 1: 130-148.

5. Deshpande K. S., 1958: Structure of ovary in the common Indian musk shrew, Suncus murinus Linn. Bull. Zool. Soc., Coll. Sci., Nagpur 1: 4-6.

6. Dryden G. L., 1966: Reproduction in Suncus murinus. Unpublished thesis, University of Missouri, Columbia.

7. Dryden G. L., 1968: Growth and development of Suncus murinus in captivity on Guam. J. Mamm., 49: 51-62.

8. Dryden G. L., 1969: Reproduction in Suncus murinus. J. Reprod. Fert., Suppl. 6: $377-396$.

9. Dryden G. L., 1975: Establishment and maintenance of shrew colonies. Int. Zoo. Yb., 15: 12-18.

10. Dryden G. L., 1985: Development and regression of the corpus luteum of pseudopregnancy in Suncus murinus. Acta Zool. Fennica 173: 263-264.

11. Dryden G. L., \& Anderson J. N., 1977: Ovarion hormone: Lack of effect on reproductive structures of female Asian musk shrews. Science, 197: 782-784.

12. Dryden G. L. \& Pucek Z., 1976: Insectivores in reproduction studies, with emphasis on ovulation in American, Asian, and European shrews [In: "The Laboratory Animal in the Study of Reproduction", Eds. Th. Antikatzides, S. Eriksen \& A. Spiegel]. Gustav Fischer Verlag: 39-50. Stuttgart,

13. Ferenczy A., Richart R. M., Agate F. J., Purkerson M. L. \& Dempsey E. W., 1972: Scanning electron microscopy of the human fallopian tube. Science, 175: $783-784$.

14. Hafez E. S. E., 1972: Scanning electron microscopy of rabbit and monkey female reproductive tract epithelium. J. Reprod. Fert., 30: 293-296.

15. Hasler M. J. \& Nalbandov A. V., 1978: Pregnancy maintenance and progesterone concentrations in the musk shrew, Suncus murinus (Order: Insectivora). Biol. Reprod., 19: 407-413.

16. Hasler M. J. \& Nalbandov A. V., 1980: Ovulation, ovum maturation and changes in plasma and adrenal progesterone concentrations in the musk shrew (Suncus murinus). Biol. Reprod., 22: 377-381.

17. Hayashi T. \& Matsukawa T., 1979: Scanning electron microscopical study on 
epithelia of the bovine genital tract. Japan J. Anim. Reprod., 25: 85-88.

18. Johannisson E. \& Nilsson L., 1972: Scanning electron microscopic study of the human endometrium. Fertil. Steril., 23: 613-625.

19. Kanagawa H., Hafez E. S. E., Pitchford W. C., Beachler C. A. \& Barnhart M. I., 1972: Surface patterns in the reproductive tracts of the rabbit observed by scanning microscopy. Anat. Rec., 174: 205-226.

20. Keefer D. A., \& Dryden G. L., 1982: Nuclear uptake of radioactivity by cells of pituitary, brain, uterus and vagina of the Asian musk shrew (Suncus murinus) following $\left[{ }^{3} \mathrm{H}\right]$ Estradiol administration. Gen. Comp. Endocrinol., 47: $125-130$.

21. Lamb J. C., Newbold R. R., Stumpf W. E. \& McLachlan J. A., 1978: Transitional changes in the surface epithelium of the cyclic mouse vagina, cervix and uterus: scanning electron microscopic studies. Biol. Reprod., 19: 701-711.

22. Ludwig H. \& Metzger A., 1976: Scanning Electron Microscopy of the Human Female Reproductive Tract. Springer-Verlag: 1-247. NY-Heidleberg.

23. Naik D. R., \& Dominic C. J., 1970: Observations on the vaginal cell types, sexual receptivity and on the mating behaviour of the musk shrew, Suncus murinus L. (Insectivora). Indian Biol., 2: 66-74.

24. Nalbandov A. V., 1969: Comparative morphology and anatomy of the oviduct [In: "The Mammalian Oviduct", Eds. E. S. E. Hafez \& R. J. Blandau]. Univ. Chicago Press: 47-55. Chicago.

25. Odor D. L., Gaddum-Rosse P., Rumery R. E. \& Blandau R. J., 1981: Cyclic variations in the oviducal ciliated cells during the menstrual cycle and after estrogen treatment in the pig-tailed monkey, Macaca nemestrina. Anat. Rec., 198: $35-58$.

26. Odor D. L., Gaddum-Rosse P. \& Rumery R. E., 1983: Secretory cells of the oviduct of the pig-tailed monkey, Macaca nemestrina, during the menstrual cycle and after estrogen treatment. Am. J. Anat., 166: 149-172.

27. Parakkal P. F., 1974: Cyclical changes in the vaginal epithelium of the rat seen by scanning electron microscopy. Anat. Rec., 178: 529-538.

28. Psychoyos A. \& Mandon P., 1971: Scanning electron microscopy of the surface of the rat uterine epithelium during delayed implantation. J. Reprod. Fert., 26: 137-138.

29. Rumery R. E., Gaddum-Rosse P., Blandau R. J. \& Odor D. L., 1978: Cyclic changes in ciliation of the oviducal epithelium in the pig-tailed macaque (Macaca nemestrina). Am. J. Anat., 153: 345-366.

30. Sabnis J. H., 1973: Post-partum changes in the uterus of Suncus murinus (Linn) (Insectivora: Soricidae). J. Biol. Sci., 16: 5-9.

31. Segalen J., Lescoat D. \& Chambon Y., 1982: Ultrastructural aspects of uterine secretion during the establishment of pregnancy in the rabbit: role of the egg. J. Anat., 135: 281-289.

32. Sperry D. G. \& Wasserburg R. J., 1976: A proposed function for microridges on ep thelial cells. Anat. Rec., 185: 253-258.

33. Takahashi J., Sugawara S. \& Masaki J., 1980: Scanning electron microscopic studies of uterine epithelial cytoplasmic protrusions during estrus cycle, pregnancy, pseudopregnancy and early stages of decidualization in rat. Tohoku J. Agricul. Res., 31: 33-41.

34. Temple-Smith P. D., 1984: Phagocytosis of sperm cytoplasmic droplets by a spe ialized region in the ep didymis of the brushtailed possum, Trichosurus vulpecula. Biol. Reprod., 30: 707-720. 
35. Verhage H. G., Abel J. H., Tietz W. J. \& Barrow M. D., 1973 a: Development and maintenance of the oviducal epithelium during the estrus cycle in the bitch. Biol. Reprod., 9: 460-474.

36. Verhage H. G., Abel J. H., Tietz W. J. \& Barrow M. D., 1973 b: Estrogen induced differentiation of the oviducal epithelium in prepubertal dogs. Biol. Reprod., 9: 475-488.

37. Verhage H. G. \& Brenner R. M., 1975: Estradiol induced differentiation of the oviducal epithelium in ovariectomized cats. Biol. Reprod., 13: 104-111.

38. Weakley B. S., 1969: Differentiation of the surface epithelium of the hamster ovary: An electron microscopic study. J. Anat., 105: 129-147.

Accepted, August 30, 1985.

Eric D. WIKRAMANAYAKE i Gilbert L. DRYDEN

\author{
STRUKTURA NABEONKA NARZĄDOW PECIOWYCH SAMIC \\ SUNCUS MURINUS BADANA ELEKTRONOWYM MIKROSKOPEM \\ SKANNINGOWYM
}

Streszczenie

Komórki powierzchniowe jajników dorosłych samic Suncus murinus są pomarszczone (Fig. 1) lub zaokrąglone (Fig. 2). Komórki te u samic poddawanych i nie poddawanych driałaniu estrogenu są często zapadnięte, natomiast u samic traktowanych HCG są zaokrąglone. Komórki nabłonkowe ciałka żółtego (Fig. 4) grzybkowatego w kształcie są okrągłe lub wielościenne (Fig. 5).

Nabłonek jajowodów składa się zarówno z orzęsionych jak i nieorzęsionych komórek (Fig. 7) i jest silnie pofałdowany. Rzęski występują na $60-70 \%$ długości jajowodów, a na pozostałej części jedynie w rozproszonych grupach (Fig. 11). Rzęski nie występują powyżej połączenia jajowodu $\mathrm{z}$ macicą, a nabłonek w tym miejscu jest zbudowany $\mathrm{z}$ płytkich, podłużnych fałd $\mathrm{z}$ licznymi kosmkami (Fig. 12). Połączenie maciczno-jajowodowe przechodzi w jamę macicy z licznymi kosmkami na zaokrąglonej powierzchni komórek (Fig. 13). Komórki nabłonkowe macicy są umiarkowanie pofałdowane i posiadają liczne kosmki na szczytach zaokrąglonych komórek (Fig. 14).

Kosmki śluzówki macicy samic poddanych działaniu estrogenu są wydłużone w niektórych miejscach i połączone z pęcherzykami wydzielniczymi.

Nabłonek szyjki macicy składa się z płaskich, kosmkowatych komórek otaczających płytkie zagłębienia, będące prawdopodobnie ujściami gruczołów wydzielniczych (Fig. 16).

Nabłonek pochwy samic poddawanych i niepoddawanych działaniu estrogenu jest głęboko podłużnie bruzdkowany, ale bruzdkowanie to ukryte jest pod złuszczającym się nabłonkiem wielowarstwowym. Komórki powierzchniowe pochwy są pokryte gęstymi, krótkimi kosmkami, przez co sprawiają wrażenie puszystych (Fig. 22). Nabłonek pochwy samic nie poddawanych działaniu estrogenu charakteryzuje się zawiłym układem mikrokrawędzi (Fig. 20, 21). 


\section{EXPLANATIONS OF PLATES I-V}

\section{Plate I}

Fig. 1. Scanning electron micrograph showing (artefactually?) collapsed ovarian: epithelial cells in Suncus murinus. $\times 4,500$.

Fig. 2. Uncollapsed, rounded ovarian epithelial cells. Patches of these were interspersed among the collapsed cells. $\times 5,500$.

Fig. 3. Collapsed ovarian epithelial cell (arrow at pit rim) showing microvilli on its surface. $\times 8,500$.

Fig. 4. Micrograph showing newly extruded fungiform corpora lutea (CL) flanking ovarian mass (OV). Note the size of the corpora relative to the ovary. $\times 100$.

Fig. 5. Surface of the corpus luteum $39 \mathrm{hr}$ after ovulation. Contrast variously shaped, large cells here with those of the ovarian surface (Fig. 6). $\times 250$.

Fig. 6. Uniformly spherical, small cells of the ovarian surface adjacent corpora: lutea in Fig. $5 . \times 250$.

Plate II

Fig. 7. Fimbrial epithelium of an estradiol-treated shrew showing extensive ciliation. Some non-ciliated cells $(\mathrm{N})$, with microvilli were present. $\times 2,500$.

Fig. 8. The fimbrial epithelium of an older, untreated shrew bore a large proportion of non-ciliated cells. In addition to the "dome-shaped" non-ciliated cells, as in the younger and estradiol-treated shrews (Fig. 7), some cells were flattened and polyhedral $(\mathrm{P}) . \times 2,500$.

Plate III

Fig. 9. Heavily folded, extensively ciliated epithelium of the oviducal ampulla. $\times 1,500$.

Fig. 10. Higher power micrograph of oviducal ciliation. A few nonciliated cells were also present $(\mathrm{N})$ but these were less numerous than in the fimbrial area. $\times 4,000$.

Fig. 11. Patches of cilia (C) set among predominant fields of nonciliated, microvillous cells characterize the distal oviduct. $\times 5,000$.

Fig. 12. Cilia were completely absent towards the utero-tubal junction. The oviducal epithelium was longitudinally plicated and the cells bore numerous microvilli. $\times 7,500$. 


\section{Plate IV}

Fig. 13. Tubal os (arrow at juncture of two rim lips) from uterine lumen. Domned surface cells were thickly covered with short microvilli. $\times 500$.

Fig. 14. Endometrial epithelium of an untreated shrew. The cell boundaries aare apparent and the cells themselves are characterized by numerous stubby micrrovilli seen in profile at arrow. $\times 5,000$.

Fig. 15. Endometrium of estradiol-treated shrew showing tuft of elongated micrrovilli centered at the apex of most cells. $\times 4,500$.

Fig. 16. Numerous (presumably secretory) extrusions such as this were prescent on the luminal surface of estradiol-treated shrew uterine epithelia. $\times 15,000$.

Fig. 17. The cervical epithelial cells were relatively flat with well-defined bouundaries. Numerous shallow depressions (d) among these cells may be gland orificces. $\times 1,200$.

Fig. 18. The fornical epithelium consisted of partially imbricated, apparently kkeratinized squamous cells. $\times 3,500$.

\section{Plate V}

Fig. 19. Vaginal epithelium of estradiol-treated shrew. Note longitudinal follds and suggestion of microridges. $\times 3,200$.

Fig. 20. Extensive microridge systems apparent on surfaces of vaginal folds in an untreated shrew. See Fig. 21. $\times 3,200$.

Fig. 21. Detail of area similar to that in Fig. 20 and having the elaborate microridge system on vaginal surface in an untreated shrew. $\times 6,500$.

Fig. 22. Stubby microvilli (M) characteristic of the luminal cell surfaces in the posterior vagina. $\times 1,000$. 

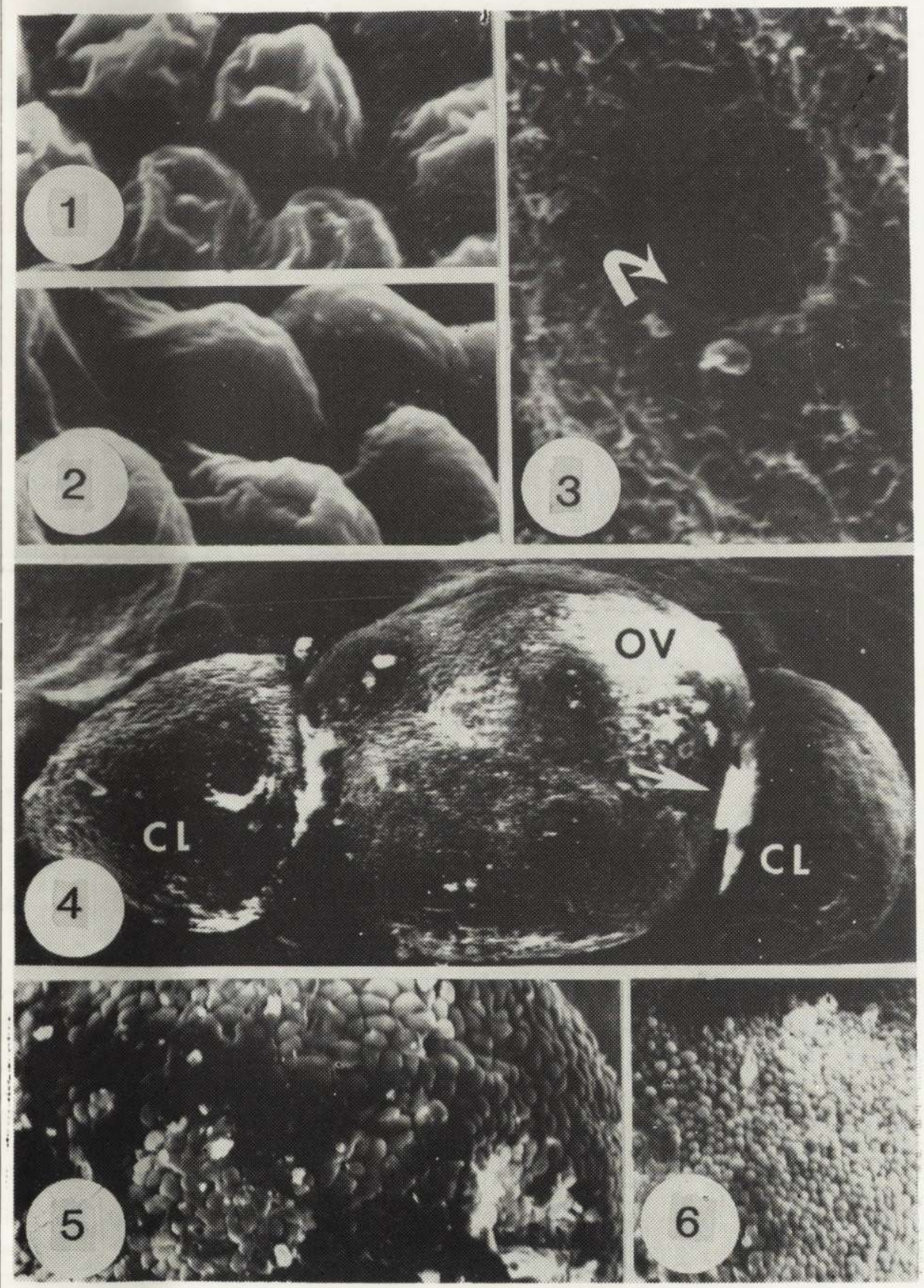

E. D. Wikramanayake \& G. L. Dryden

auctores phot. 


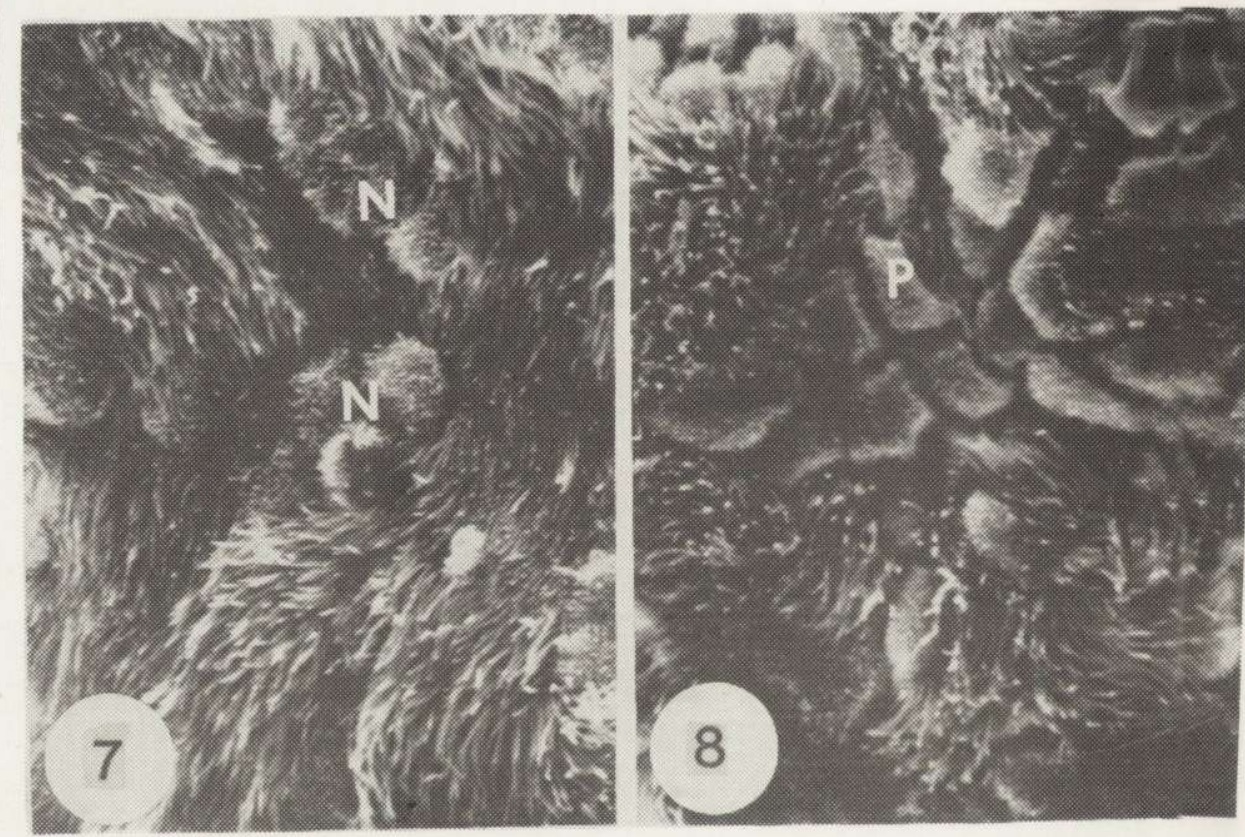




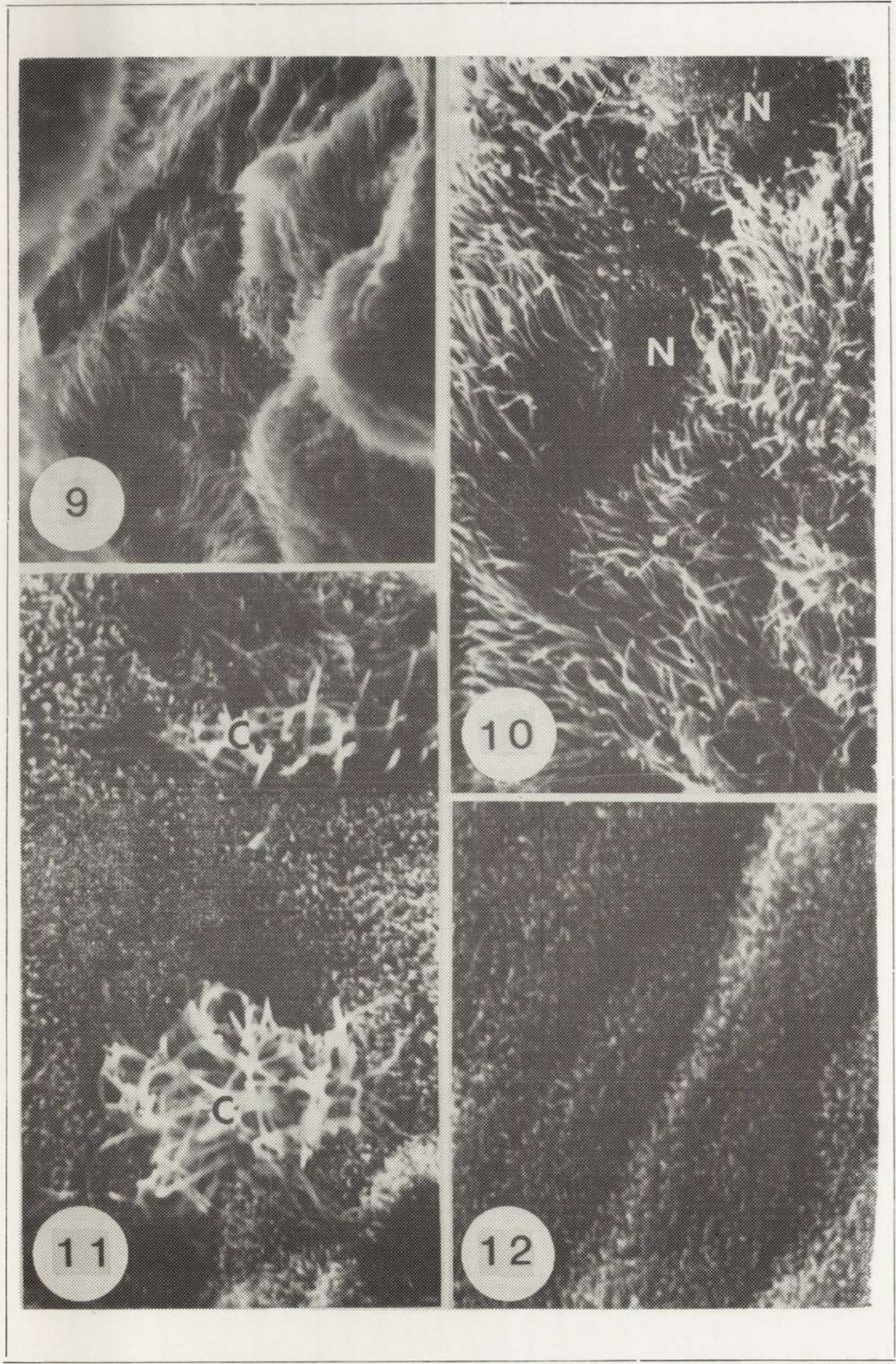

E. D. Wikramanayake \& G. L. Dryden auctores phot. 


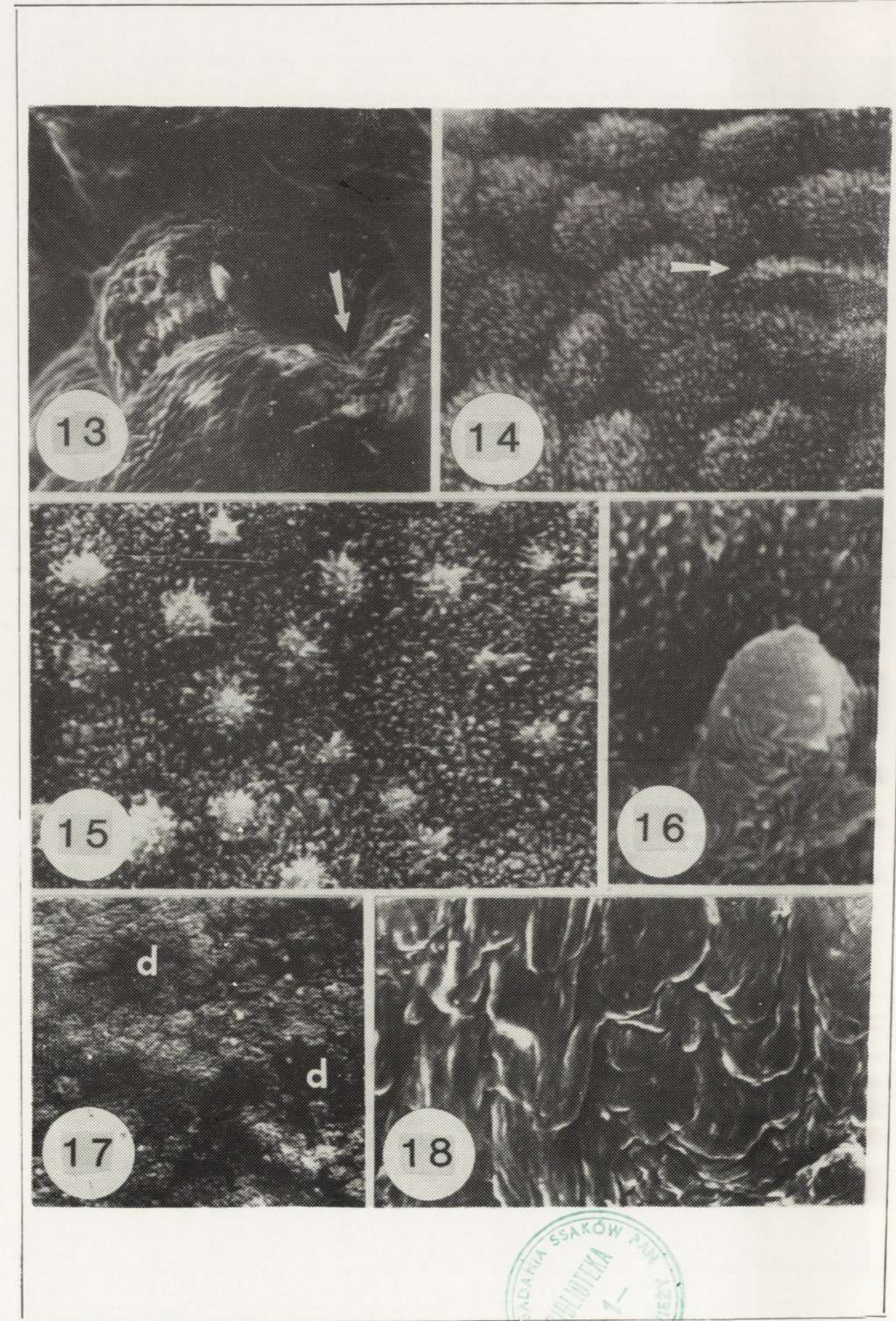

E. D. Wikramanayake \& G. L. Dryden auctores phot. 


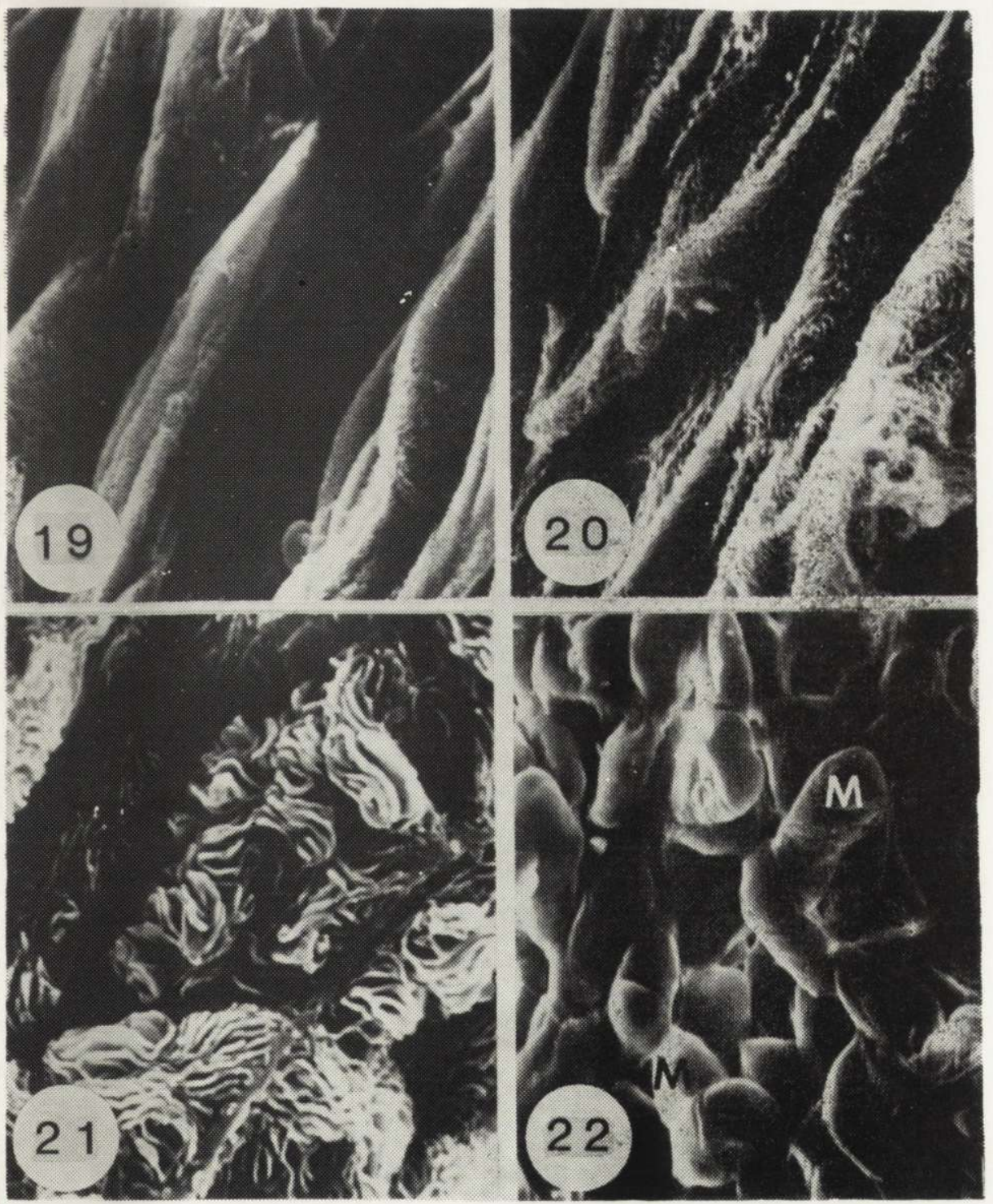

